\title{
Role of Diffusion-Weighted Magnetic Resonance Imaging in Detecting and Characterizing Benign and Malignant Liver Tumors in Adults
}

\author{
DINA HAMZAWY, M.Sc.; MEDHAT MADBOULY, M.D.; SHIMAA DESOUKY, M.D.; MONA HASSAN, M.D.; \\ AHMED ABDELSAMIE, M.D. and HAMED EL-GHAWABY, M.D.
}

The Department of Radiodiagnosis, Theodor Bilharz, Research Institute, Cairo, Egypt

\begin{abstract}
Background: DWI is done by quantifying the amount of diffusion through tissues and calculating ADC values. Tumors, which consist of excessive proliferation of cells, would expectantly show restricted diffusion. ADC values can aid in characterizing focal liver lesions as benign vs. malignant. DWI when used in combination with dynamic MRI can be used to enhance the accuracy of liver lesion characterization and diagnosis.
\end{abstract}

Aim of Study: To assess the role of diffusion-weighted magnetic resonance imaging (DWI) in detection and characterization of hepatic focal lesions, and its value in differentiating benign from malignant masses.

Patients and Methods: A total of 60 liver disease patients ( 21 males and 39 females) with ages ranged from 20 to 63 years old were included in the study. All of the patients underwent MRI examination including pre-contrast imaging, dynamic study and diffusion study. The morphological features of each lesion were recorded and diffusion images were reviewed for final radiological characterization and detection of focal lesions. ADC values were calculated for all patients.

Results: This study included 60 patients with various types of lesions, 40 of which had benign lesions and 20 with malignant lesions. The diffusion images aided in diagnosis of malignant lesions with different components. Absolute ADC values of different types of lesions were not similar. Benign hepatic lesions have generally higher ADC values compared with malignant lesions. The ADC values we found for different lesions were consistent with previous studies.

Conclusion: Diffusion-weighted MRI sequence with quantitative ADC measurement should be used as an additional sequence to supplement conventional MRI protocol studies for proper detection and characterization of solid liver lesions.

Key Words: Liver - DW-MRI.

Correspondence to: Dr. Dina Hamzawy, The Department of Radiodiagnosis, Theodor Bilharz Research Institute, Cairo, Egypt

\section{Introduction}

THE liver is an organ in which benign or malignant masses can be detected. Traditionally, focal masses are diagnosed using ultrasonography and/or computed tomography [1]. Accurate detection and characterization of these lesions are important for treatment planning in cases such as Hepatocellular Carcinoma (HCC) and metastases. The size and numbers of lesions affect therapy strategies.

Magnetic resonance imaging is preferred when further characterization of these masses is needed. The conventional technique of MRI liver included non-enhanced MR sequences such as T1-weighted sequences and T2-weighted sequences. There are also contrast-enhanced MR sequences and dynamic study that uses a variety of contrast agents with Gadolinium chelates being the most widely used [2].

Throughout the years, studies using the Diffusion-Weight Imaging (DWI) technique have shifted from being limited to brain studies to including other studies on lymphadenopathy and liver lesions. The benefit of DWI is that it more accurately and clearly identifies liver lesions. For example, many liver lesions demonstrate low $\mathrm{T} 1$ and bright $\mathrm{T} 2$ signal which is similar to hepatic vessels and the bile ducts. With DWI, bile ducts and vessels are shown as black as the liver which allows even small lesions to be highlighted [3]. Additional advantages include high contrast resolution, lack of ionizing radiation and safety of contrast not containing iodine [1].

The DWI signal is derived from motion of water molecules throughout biologic tissue. This qualitative assessment of DWI is done via $b$ values. 
The sensitivity of the imaging sequence to water diffusion can be altered by changing the $b$ value. By running a series of DW sequences at various strengths, images are produced sensitized to diffusion in multiple different directions [4].

At a value of $0 \mathrm{sec} / \mathrm{mm}^{2}$, free water molecules have a high signal intensity. Small $b$-values (from $50-100 \mathrm{sec} / \mathrm{mm}^{2}$ ) result in signal loss in highly mobile water molecules such as within vessels. Since water movement in highly cellular tissues, such as in tumors, is restricted, the water molecules within such tissue retain their signal even at high $b$-values $\left(500-1000 \mathrm{sec} / \mathrm{mm}^{2}\right)$ [4]. The degree of restriction to water diffusion throughout the tissue is inversely correlated to tissue cellularity and theintegrity of cell membranes.

Quantitative analysis of DWI is done by the means of an Apparent Diffusion Coefficient (ADC) . It is a reflection of the amount of diffusion and is affected by several factors in biological tissues; capillary perfusion, temperature, magnetic sensitivity of the tissue and motion [5,6]. Analysis of ADC is an automated process that is represented as a parametric map that reflects the differences in tissue diffusivity at different $b$ values (at least two). ADC can aid in characterization of liver lesions as well as for assessment of tumor response to treatment and diagnosis of liver fibrosis and cirrhosis [7].

In the context of tumor characterization, reduced ADC values have been reported in most malignant tumors due to reduced diffusion. However, solid benign lesions, which are also highly cellular, exhibit decreased ADC values as well. Benign lesions as simple cysts and hemangiomas show high ADC values because of their liquid content and large extracellular spaces. However, ADC values cannot discriminate between solid benign and malignant lesions since there is considerable overlap [8].

DWI can help direct the attention of the radiologist to findings that may otherwise be overlooked. Unenhanced and dynamic MRI contrast series alone are very capable in the discrimination of different types of liver lesions, but a combination of DWI and MRI increases the accuracy of the characterization of benign and malignant lesions [8].

The aim of this study is to assess the role of diffusion-weighted magnetic resonance imaging ( DWI) in detection and characterization of hepatic focal lesions, and its value in differentiating benign from malignant masses.

\section{Material and Methods}

In this prospective study, a total of 60 patients ( 21 males and 39 females) with ages ranged from 20 to 63 years old (mean age 49) were included in the study in the period from June 2012 to June 2013.

15 of the patients had their MRI done at Cairo Scan Radiology Center in Egypt. The remaining 35 patients had their examinations done at the Université Libre De Bruxelles in Belgium.

\section{Inclusion criteria:}

- Adults (18+).

- Patients with focal liver lesions (malignant or benign).

Exclusion criteria:

- Anyone under 18 years old.

- Patients with diffuse liver lesions (including inflammations).

Laboratory investigations, Ultrasonography ( US) and/or CT and a detailed MRI were done for all patients.

\section{MRI examination:}

Conventional MRI, post Gd-DTPA dynamic and diffusion MR imaging were performed after informed written consent was obtained prior to the study.

First, blind detection and characterization of the focal lesions were done. Second, the diffusion images were reviewed as well as the ADC values of the lesions calculated. All imaging results were verified against a standard of reference. MR imaging was performed on high field system (1.5 Tesla) magnet units (Philips Intera and achieva and Siemens MAGNETOM Symphony) using a phased array coil to cover the whole liver.

Respiratory triggering technique was used.

In our study, we used three different $b$-values which were b0, b500 and b1000.

\section{Imaging evaluation:}

The morphological features of each lesion were recorded included size, shape, margin, signal characteristics, pattern of enhancement in the dynamic imaging as well as number and site of the detected focal lesions. Then provisional diagnosis was reported. Second, we reviewed the diffusion images for final radiological characterization and detection of focal lesions. 


\section{ADC calculation:}

ADC values were calculated for all patients and the mean ADC of each focal lesion detected is measured by drawing a region of interest over the lesion. The ADC was measured twice and the two measurements were averaged. To ensure that the same areas were measured, regions of interest were copied and pasted from DW images to ADC maps. Analysis was done by an automated application available on the scanner.

Table (1): Shows the MR protocol that was performed in both institutes.

\begin{tabular}{|c|c|c|}
\hline Pre-contrast imaging & Dynamic study & Diffusion study \\
\hline $\begin{array}{l}\text { T1 weighted images: } \\
\text { Repetition time }(\mathrm{TR})=10 \mathrm{msec} \\
\text { Echo time }(\mathrm{TE})=4.58 \mathrm{msec} \\
\text { Matrix } 179 / 320 \\
\text { Slice thickness } 7-8 \mathrm{~mm} \\
\text { Slice gap } 1-2 \mathrm{~mm} \\
\text { FOV: } 355 \mathrm{~mm} . \\
\text { T2 weighted images: } \\
\text { TR } \geq 445 \mathrm{~ms} \\
\text { TE = } 26-28 \mathrm{msec} \\
\text { Matrix } 180-200 \mathrm{X} 240 \text { with a field of view: } 365 \\
\text { Slice thickness } 7-8 \mathrm{~mm} \\
\text { Slice gap } 1-2 \mathrm{~mm} . \\
\text { (Free-breathing, one shot technique) } \\
\text { In phase and out phase gradient echo sequence (Dual/FFE): } \\
\text { TR = } 75-100 \mathrm{msec} \text {, } \\
\text { TE = } 4.6 \mathrm{msec} \text { for in phase and } 2.3 \mathrm{msec} \text { for out phase } \\
\text { Matrix } 143 \mathrm{X} 240 \text { with a field of view: } 345 \\
\text { Slice thickness } 7-8 \mathrm{~mm} \\
\text { Slice gap: Omm. } \\
\text { Heavy T2 weighted images: } \\
\text { TR = 520msec } \\
\text { TE = } 200 \mathrm{msec} \\
\text { Matrix } 235 / 384 \text { with a field of view: } 375 \\
\text { Slice thickness: } 7-8 \mathrm{~mm} \\
\text { Slice gap } 1-2 \mathrm{~mm} \text {. }\end{array}$ & $\begin{array}{l}\text { Performed after bolus } \\
\text { injection of } 0.1 \mathrm{mmol} / \mathrm{kg} \\
\text { body weight of Gd-DTPA at } \\
\text { a rate of } 2 \mathrm{ml} / \mathrm{s} \text {, flushed with } \\
20 \mathrm{ml} \text { of sterile } 0.9 \% \text { saline } \\
\text { solution from the antecubital } \\
\text { vein. The injection of con- } \\
\text { trast media and saline solu- } \\
\text { tion was performed manual- } \\
\text { ly. Dynamic imaging using } \\
\text { T1 THRIVE (High Resolu- } \\
\text { tion Isotropic Volume Ex- } \\
\text { amination) technique was } \\
\text { performed in triphasic way [ } \\
\text { arterial phase (16-20sec.), } \\
\text { porto-venous phase ( } 45- \\
60 \text { sec.) and delayed equilib- } \\
\text { rium phase (3-5min.)] after } \\
\text { administration of contrast } \\
\text { media. }\end{array}$ & $\begin{array}{l}\text { Respiratory-triggered } \\
\text { fat-suppressed single-shot } \\
\text { echoplanar DW imaging } \\
\text { was performed in the trans- } \\
\text { verse plane with tri- } \\
\text { directional diffusion gradi- } \\
\text { ents by using b-values 0, } \\
500 \text { \& } 1000 \text { sec/mm }{ }^{2} \text { to in- } \\
\text { crease sensitivity to cellular } \\
\text { packing. Parallel imaging } \\
\text { with generalized auto- } \\
\text { calibrating partially parallel } \\
\text { acquisition (GRAPPA) with } \\
\text { an acceleration factor of } \\
\text { two was applied to improve } \\
\text { image quality. The other } \\
\text { parameters were as follows: } \\
\text { Repetition time (TR) }>1880 \\
\text { msec, echo time (TE) }=70 \\
\text { msec, number of excita- } \\
\text { tions (NEX) = } 3 \text {, matrix } \\
256 \text { X } 256 \text { with a field of } \\
\text { view as small as possible } \\
\text { with } 52 \% \text { rectangular field } \\
\text { of view, slice thickness } 7- \\
8 \text { mm, slice gap } 1-2 \text { mm, } \\
\text { scan time } 3-4 \text { min. }\end{array}$ \\
\hline
\end{tabular}

\section{Results}

All of the patients were subjected to both diffusion and dynamic study. All of the images were technically appropriate and presented a good quality.

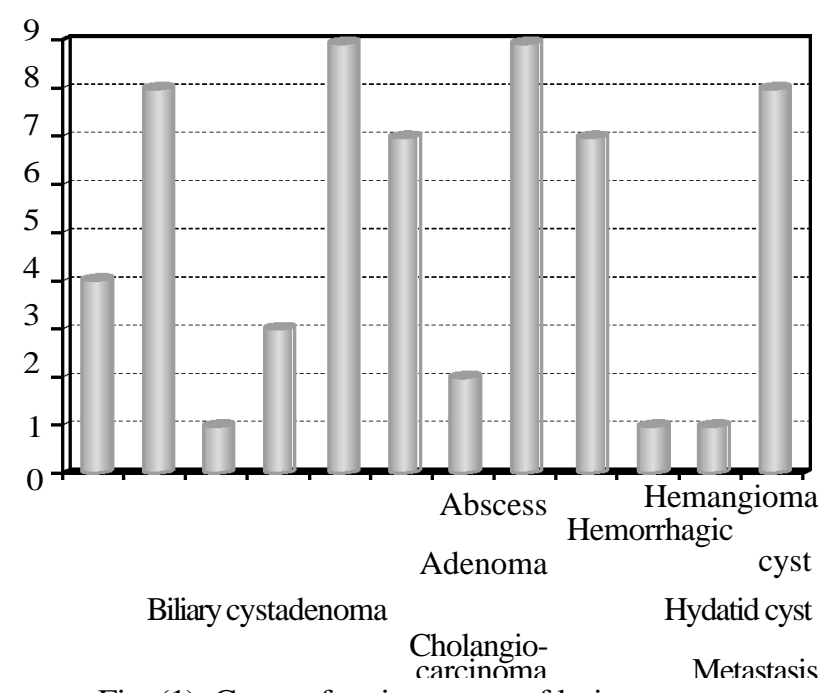

Fig. (1): Count of various types of lesions.
$\%$ Split of patients/lesion category

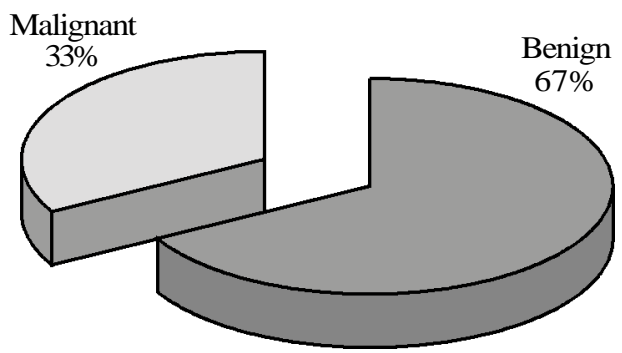

Fig. (2): Percentage of small and large lesions.

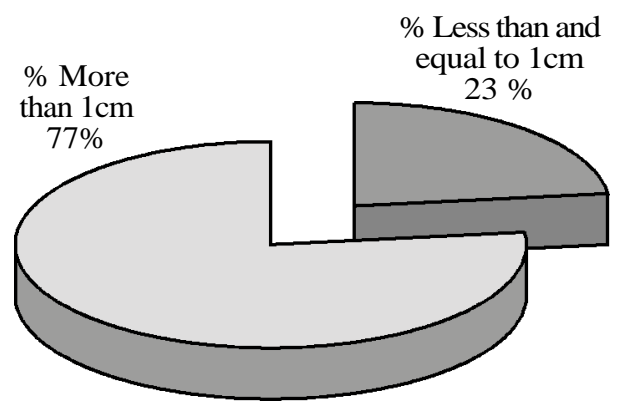

Fig. (3): Percentage of lesions according to their 


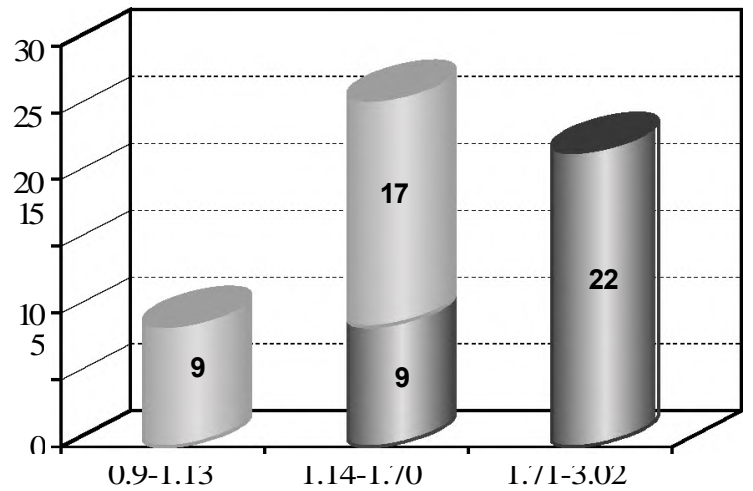

$\square$ Malignant $\square$ Benign

Fig. (4): Range of ADC values of benign and malignant lesion.

Cysts

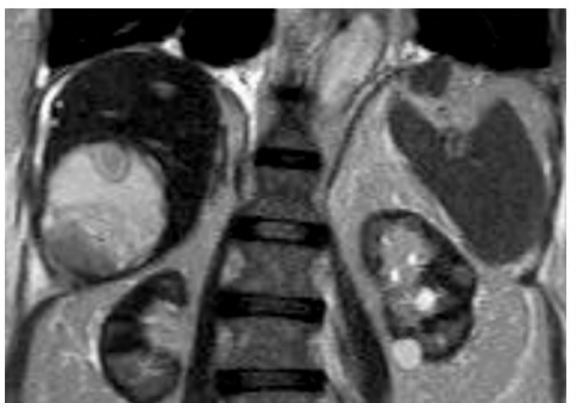

(5A) Coronal $\mathrm{T} 2 \mathrm{~W} 1$

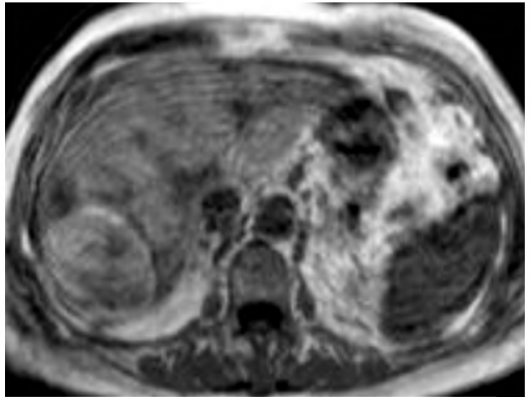

(5B) Axial T1W1

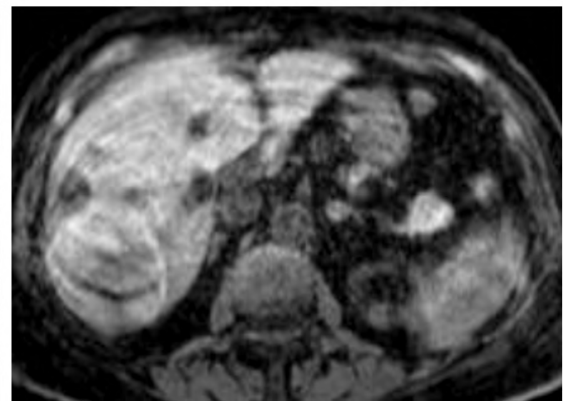

(5C) Axial T1 fat suppression W1

Fig. (5): (A-C) Coronal T2WI, Axial T1WI and T1 Fat suppression WI respectively. Imaging of a patient showing a large right infero-posterior hepatic lobe (segment VI) cystic lesion. Hyperintense T2 and hypointense T1 signal intensities with areas of hypointense T2 and hyperintense T1 signal intensities which persistently appear hyperintense in T1 fat suppression. Images likely representing hemorrhagic component.

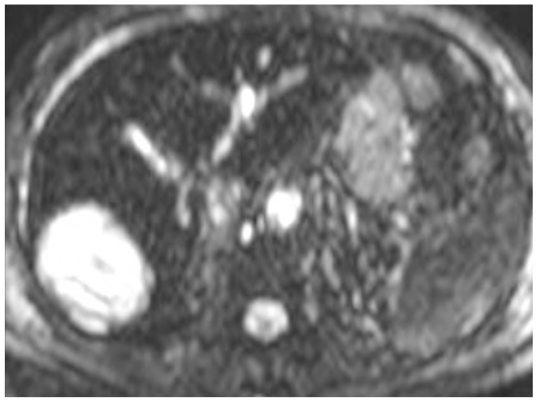

(5D) Axial DWI b500

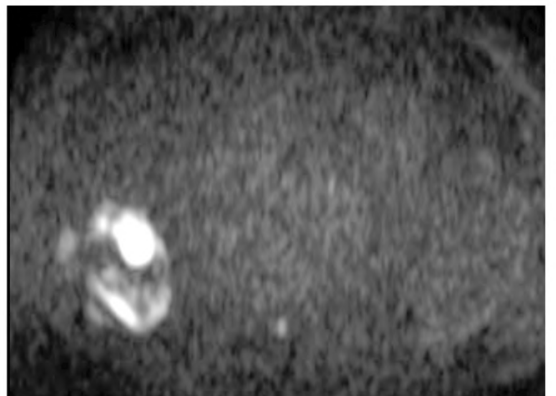

(5E) Axial DWIs b1000

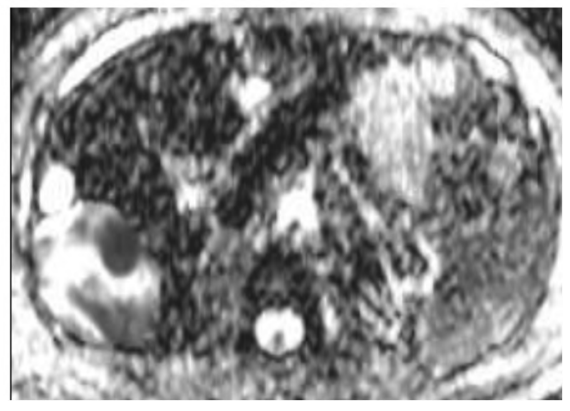

(5F) Axial ADC map

Fig. (5): (D-F) Axial Diffusion WIs b500 and b1000, ADC map respectively, patient with right hepatic lobe cystic lesion that appears to be bright in the DWI with b-value 500 due to the T2 shine through effect and with increasing the bvalue it became less bright due to masking of the T2 effect, while the hemorrhagic areas appear heterogeneously bright in the DWIs. In the ADC map the cyst appeared bright with the hemorrhagic areas appearing of low signal intensity.

\section{Hepatocellular Carcinoma}

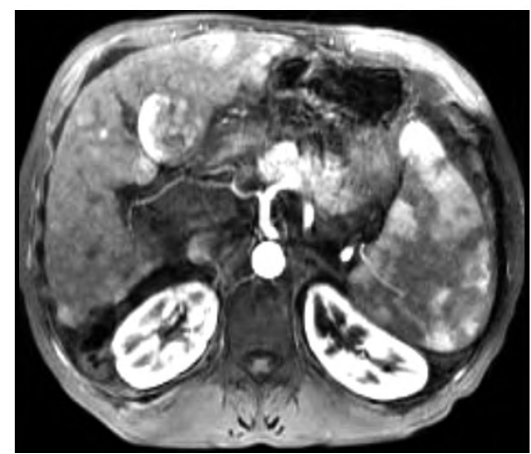

(6A) Axial post contrast T1 arterial

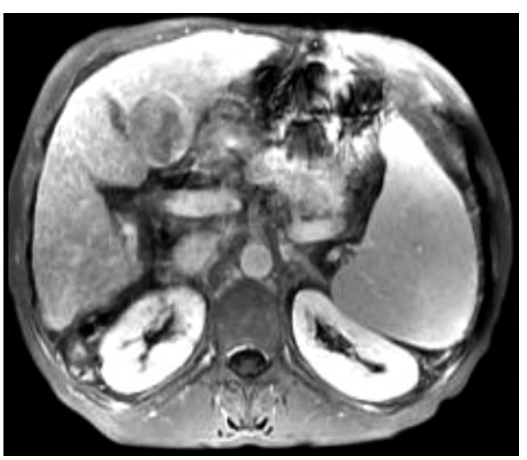

(6B) Axial post contrast $\mathrm{T} 1$ porto-venous
Fig. (6): (A, B) Axial post contrast $\mathrm{T} 1$ WIs arterial and porto-venous phases, imaging of a patient showing a left hepatic lobe well defined focal lesion showing intense early arterial enhancement with wash out of contrast in the porto-venous phase. 


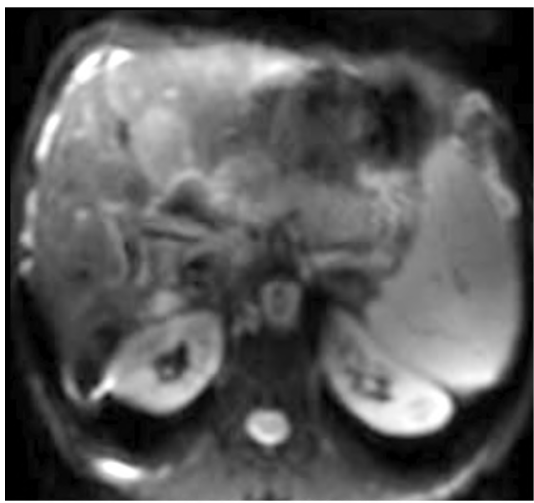

(6C) Axial DWI b500

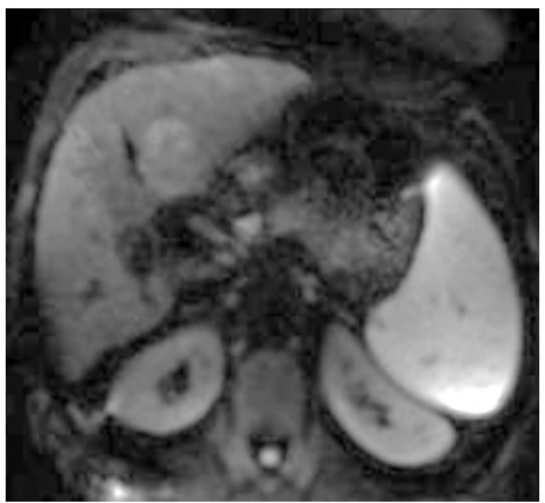

(6D) Axial DWI b1000

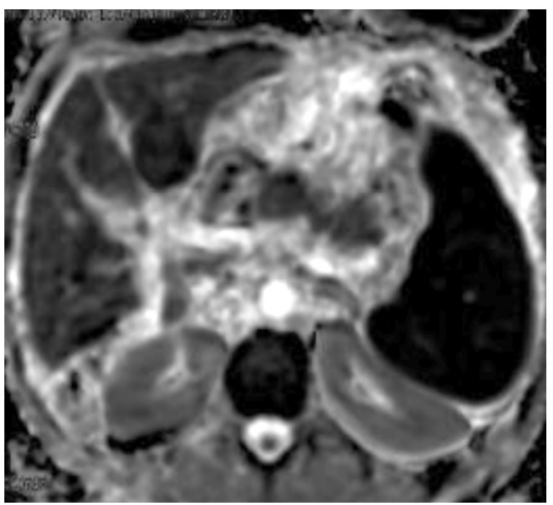

(6E) Axial ADC map

Fig. (6): (C-E) Axial diffusion WIs b500 and b1000, Axial ADC map, showing the previously seen left hepatic lobe focal lesion being bright in the diffusion WIs at both b-values 500 and 1000, while the lesion appears of low signal intensity in ADC map denoting restriction.

\section{Adenoma}

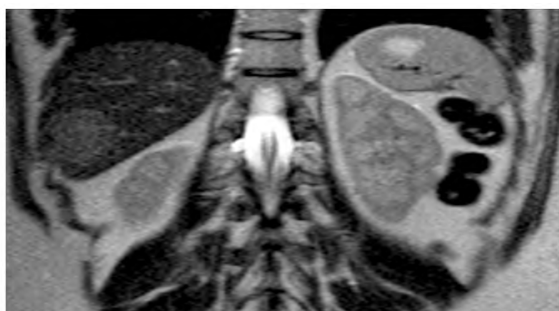

(7A) Coronal T2 WI

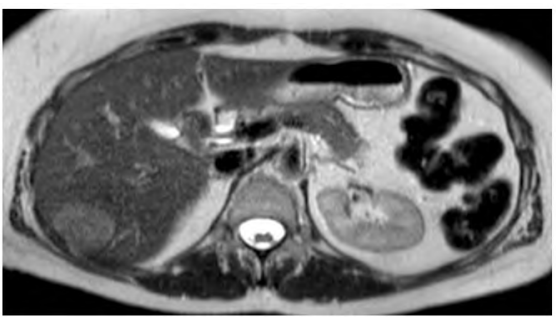

(7B) Axial T2WI

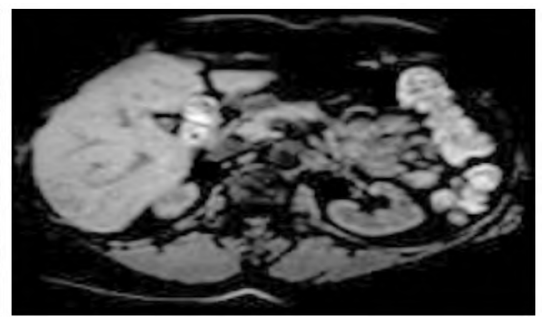

(7C) Axial T1 Fat suppression

Fig. (7): (A, B) Coronal and Axial T2 Wis patient imaging showing a right hepatic lobe rather rounded hyperintense focal lesion. (C) Axial T1 fat suppression showing the right hepatic lobe focal lesion being hypointense denoting fatty content of the lesion suggesting the possibility of adenoma.

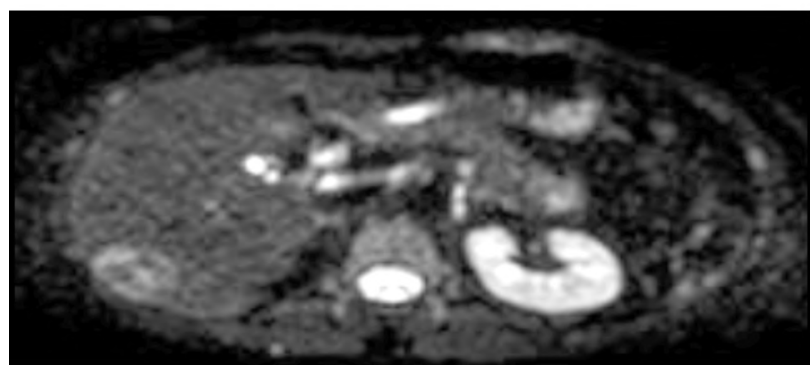

(7D) Axial DWI b0

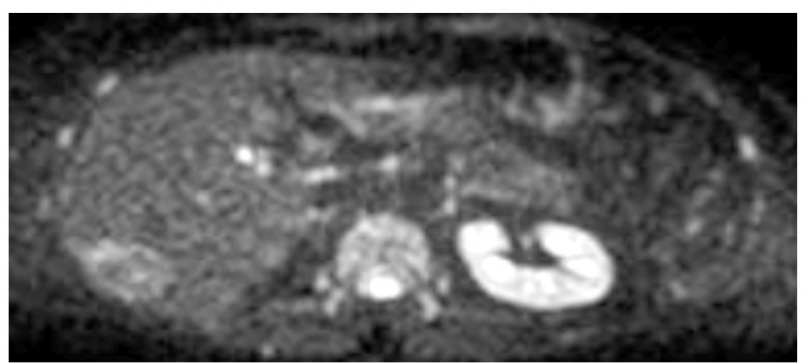

(7F) Axial DWI b1000

\section{Discussion}

Although T 1 and T2 weighted MRI images are able to localize liver lesions, the drawback is that

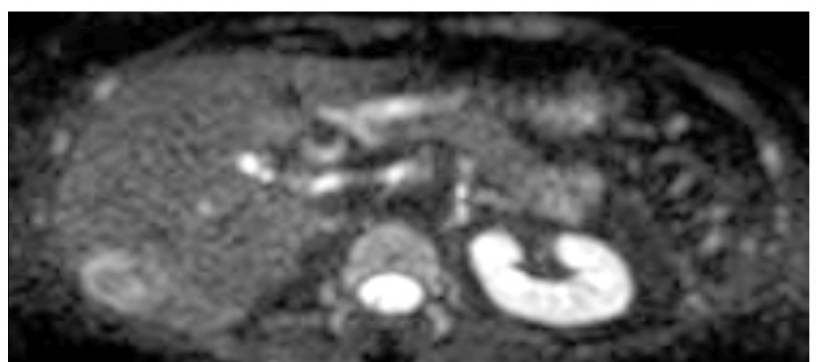

(7E) Axial DWI b500

Fig. (7): (D-F) Axial diffusion WIs b0, b500 and b 1000, showing the right hepatic lobe focal lesion being hyperintense at the three different $b$ values denoting restriction within the lesion.

lesions appear similar to ducts and vessels, creating a need for more diagnostic imaging techniques. Diffusion imaging allows for focal liver lesions tobe more accurately described. 
In this study, a total of 60 patients underwent a series of imaging protocols, shown in (Table 1), in order to characterize their liver lesion. In our study, three different b-values were used which is in line with studies performed by Qayyum, 2009 and Parikh et al., 2008. The use of low b-value (b0 $\mathrm{sec} / \mathrm{mm}^{2}$ ) was beneficial in detection of focal lesions. This is due to the signal loss in highly mobile water molecules such as those within vessels. The use of higher be values (500$100 \mathrm{~mm} / \mathrm{sec}^{2}$ ) was of use in tissue characterization which was due to the restriction of water movement in highly cellular tissues such as tumors and therefore these tissues retain their signal even at high b-values

$[4,7]$.

As a general observation, both benign and malignant solid lesions may demonstrate residual high signal intensity on higher $b$ value images and this makes it difficult to depend only on inspecting and reviewing the images to characterize the lesion's nature.

This is highlighted in previous studies (Taouli and Koh, 2010 and Parikh et al., 2008) showing that it is difficult to characterize focal lesions with visual assessment of the DW MR images alone. Hence, once a cellular hepatic lesion is identified visually, further characterization usually relies on conventional morphologic (with or without contrast enhancement) imaging, supplemented with ADC measurements.

Our study included various types of liver lesions that varied in size, type and multiplicity which are represented in Figs. (1-4). The diffusion images aided in diagnosis of malignant lesions with different components which agreed with conclusion made by Taouli and Koh, 2010, that DW MR imaging is useful in distinguishing the different components of tumors (cystic and/or necrotic vs. solid components).

Wide range of ADC values were detected which varied between the benign and malignant lesions with the following ranges Fig. (4):

- Malignant lesions ranged from $0.9 \times 10^{-3}$ to 1.13 $\mathrm{X} 10^{-3} \mathrm{~mm}^{2} / \mathrm{sec}$.

- Benign lesions ADC values ranged from $1.71 \mathrm{X}$ $10^{-3}$ to $3.02 \times 10^{-3} \mathrm{~mm}^{2} / \mathrm{sec}$.

- The range of ADC values that the benign and malignant focal lesions overlapped ranged from $1.14 \times 10^{-3}$ to $1.70 \times 10^{-3} \mathrm{~mm}^{2} / \mathrm{sec}$.

The absolute ADC values of the different types of lesions were not similar, which is probably due to diffarannas in tarhnimus onnliad / $h$ volua hrasth measurement methods, and mathematical technique applied). This finding was also stated by Kele and Van der Jagt, 2010, where they stated that in spite of the increasing number of studies dealing with quantitative measurements of $\mathrm{ADC}$ in liver lesions, there are many discrepancies in the reported ADC values with no defined cut-off value for ADC values in normal parenchyma, benign and malignant lesions. This is often associated with many technical parameters such as the use of respiratory-triggered versus breath-hold diffusion-weighted protocol. Respiratory triggering technique was used in our study which was suggested by Taouli and Koh, 2010, who mentioned that when assessing liver lesions, this technique results in high-quality images with good anatomic details.

It was noted, in our study, that benign hepatic lesions have generally higher ADC values compared with malignant lesions Fig. (4). However, variable degree of overlap was noted with no definite cut off value, which was also mentioned in previous studies $[\mathbf{7 , 9 , 1 0 ]}$. This could differ based on.

Although there is no definite ADC cutoff value, our study showed similar findings to those found in other studies as:

Cysts (including simple cysts, hemorrhagic cysts, hydatid cysts) $\left(2.4 \pm 0.80 \times 10^{-3} \mathrm{~mm}^{2} / \mathrm{sec}\right)$ had the highest mean ADC values in the present study, which was in line with other studies such as Miller et al., 2010, with mean ADC value of 3. $40 \pm 0.48 \times 10^{-3} \mathrm{~mm}^{2} / \mathrm{sec}$. Koike et al., 2009 found a mean $\mathrm{ADC}$ value of $2.61 \pm 0.45 \times 10^{-3} \mathrm{~mm}^{2} / \mathrm{sec}$. Bruegel et al., 2008, revealed a mean ADC value of $3.02 \pm 0.31 \times 10^{-3} \mathrm{~mm}^{2} / \mathrm{sec}$. Parikh et al., 2008, with mean ADC value of $2.54 \pm 0.67 \times 10^{-3} \mathrm{~mm}^{2} / \mathrm{sec}$. An example of one of the patients that was diagnosed with a cyst is shown in Fig. (5).

The ADC value detected for hepatocellular carcinoma, the most common primary malignant liver lesion, showed an $\mathrm{ADC}$ value ranging from from $1.05 \times 10^{-3}$ to $1.38 \times 10^{-3} \mathrm{~mm}^{2} / \mathrm{sec}$ which was nearly similar to the study conducted by Parikh et al., 2008. Showing ADC values of $1.31 \mathrm{X} \mathrm{mm}^{2} /$ sec $\pm 0.3310^{-3}$. Imaging for a patient with hepatocellular carcinoma is shown in Fig. (6).

There was a significant overlap between ADC values of adenoma (mean ADC value of $1.28 \pm 0$. $13 \times 10^{-3} \mathrm{~mm}^{2} / \mathrm{sec}$ ) and the ADC values of the different malignant lesions with no statistically significant differences. Unfortunately, it wasn't possible to differentiate between them on basis of their ADC values nor on their appearance on DWIs, as they all show restricted diffusion. This data was in line 
with Miller et al., 2010 and Parikh et al. 2008, they found considerable overlap of solid benign and solid malignant lesions and stated that there were no statistically significant difference in ADC values between hepatic adenomas, focal nodular hyperplasia, cholangiocarcinoma and hepatocellular carcinoma. Imaging for a case of adenoma shown in Fig. (7).

We discovered that there can be substantial overlap in the range of values between different pathologies so the ADC should be interpreted concurrently with all available imaging before making the radiological diagnosis as previously suggested [5,7].

\section{Conclusion:}

In our study, we concluded that diffusionweighted MRI sequence with quantitative ADC measurements should be used as an additional sequence to supplement conventional MRI protocol studies for proper detection (using low $b$-values) and characterization (using high $b$-values) of solid liver lesions.

Overall, DWI can potentially improve care of patients with cancer and cirrhosis by improving liver lesion detection over that achieved with standard breath-hold T2-weighted imaging and can be used to supplement conventional MRI protocol studies for proper characterization of solid liver lesions.

\section{References}

1- TOKGOZ O., UNLU E., UNAL I., et al.: Diagnostic value of diffusion weighted MRI and ADC in differential diagnosis of cavernous hemangioma of the liver. Afr. Health Sci., 16: 227-33. https://doi.org/10.4314/ahs.v16i1.30, 2016.
2- GANDHI S.N., BROWN M.A., WONG J.G., AGUIRRE D. A. and SIRLIN C.B.: MR contrast agents for liver imaging: What, when, how. Radiographics, 26: 1621-36. https://doi.org/10.1148/rg.266065014, 2006.

3- SAITO K., TAJIMA Y. and HARADA T.L.: Diffusionweighted imaging of the liver: Current applications. World J. Radiol., 8: 857. https://doi.org/10.4329/wjr.v8.i11. $\underline{857,2016 .}$

4- QAYYUM A.: Diffusion-weighted imaging in the abdomen and pelvis: Concepts and applications. Radiographics, 29: 1797-810. https://doi.org/10.1148/rg.296095521, 2009.

5- PARIKH T., DREW S.J., LEE V.S., et al.: Focal liver lesion detection and characterization with diffusionweighted MR imaging: Comparison with standard breathhold T2-weighted imaging. Radiology, 246: 812-22. https://doi.org/10.1148/radiol.2463070432, 2008.

6- DEMIR ÖZGÜN, OBUZ F., SAGOL Ö. and DICLE O.: Contribution of diffusion-weighted MRI to the differential diagnosis of hepatic masses. Diagnostic Interv Radiolgy June: 81-6, 2007.

7- TAOULI B. and KOH D.M.: Diffusion-weighted MR imaging of the liver. Radiology, 254: 47-66. https:// doi.org/10.1148/radiol.09090021, 2010.

8- KELE P.G. and VAN DER JAGT E.J.: Diffusion weighted imaging in the liver. World J. Gastroenterol., 16: 156776. https://doi.org/10.3748/wjg.v16.i13.1567, 2010.

9- VOSSEN J.A., BUIJS M., LIAPI E., ENG J., BLUEMKE D. A. and KAMEL I.R.: Receiver operating characteristic analysis of diffusion-weighted magnetic resonance imaging in differentiating hepatic hemangioma from other hyper-vascular liver lesions. J. Comput. Assist. Tomogr., 32: 750-6. https://doi.org/10.1097/RCT. 0b013e31816a6823,2008.

10- BRUEGEL M., GAA J., WALDT S., et al.: Diagnosis of Hepatic Metastasis: Comparison of Respiration-Triggered Diffusion-Weighted Echo-Planar MRI and Five T2Weighted Turbo Spin-Echo Sequences. Am. J. Roentgenol., 191: 1421-9. https://doi.org/10.2214/AJR.07.3279, 2008. 


\section{دور الرنين المغناطيسى بإستخدل الحئم خاصية الإنتشار

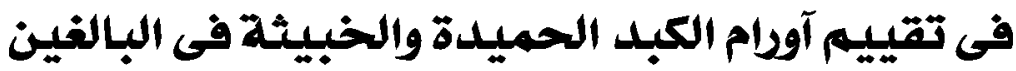

البؤد التى تصيب الكبد تكنف إما بئد حميدة آو سرطانية. ولعلاج تلك البؤد يتطلب تشخيص دقيق لتحديد نوعيتها، ويعتمد التشخيص بشكل

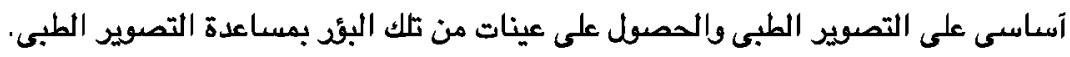

التصوير بالرنين المغناطيسى يعلب لوراً متزايد الآهمية فى تقييم المرضى الذين يعانون من آمراض الكبد بسبب خلوه من الإشعاعات

الرنين المغناطيسى له القدرة على تشخيص الكثير من الآودام حتى بدون حقن صبغة آو آخذ عينة مثل الوحمات الكبدية والآكياس. يعتمد التصوير بالرنين المغناطيسى التقليدى فى تقييم البؤد الكبدية على تقنيات ثالاث آساسية وهى T1, T2 وتقنية T1 بالصبغة التقليدية

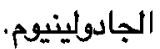

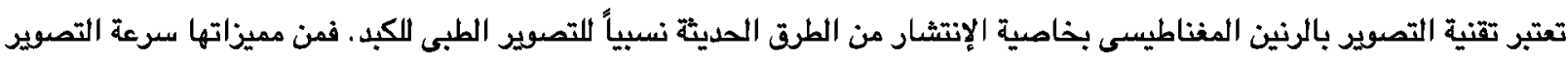

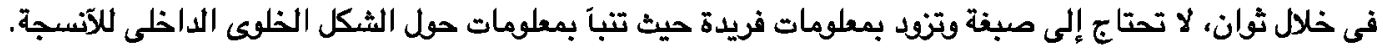

آيضاً خرائط معامل الإنتشار الظاهرى (ADC) (وهى من تقنيات الرنين المغناطيسى بالإنتشار) تزود بقياسات عداية حل إنتشارية الماء

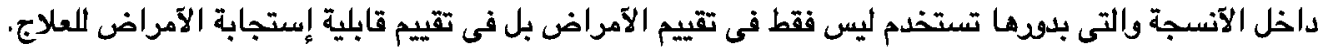

وقد آثبت هذا البحث فاعلية الرنين المغناطيسى بخاصية الإنتشار مع إستخدام قياسات معامل الإنتشار الظاهرى العددية ثُبت فعاليتها في تحديد نوعية الأورام من حميدة أو سرطانية. بوجه عام الآودام الحميدة لها قيم عددية آعلى من الآقدام السرطانية بالنسبة لمعامل الإنتشار الظاهرى مع وجود بعض التداخلات فى القيم ما بين آنواع الآودام المختلفة. يجب إستخدام الرنين المغناطيسى بخاصية الإنتشار كعامل مساعد إلى جانب الرنين المغناطيسى التقليدى لتصديد نوعية الآورام. 